University of Nebraska - Lincoln

DigitalCommons@University of Nebraska - Lincoln

Faculty Papers and Publications in Animal

Science

Animal Science Department

January 1965

\title{
EFFECT OF FERROUS FUMARATE IN THE LACTATION DIET ON SOW MILK IRON, PIG HEMOGLOBIN AND WEIGHT GAIN
}

\author{
T. L. Veum \\ Cornell University \\ J. T. Gallo \\ Cornell University \\ L. Dale Van Vleck \\ University of Nebraska-Lincoln, dvan-vleck1@unl.edu \\ J. K. Loosli \\ Cornell University
}

Follow this and additional works at: https://digitalcommons.unl.edu/animalscifacpub

Part of the Animal Sciences Commons

Veum, T. L.; Gallo, J. T.; Van Vleck, L. Dale; and Loosli, J. K., "EFFECT OF FERROUS FUMARATE IN THE LACTATION DIET ON SOW MILK IRON, PIG HEMOGLOBIN AND WEIGHT GAIN" (1965). Faculty Papers and Publications in Animal Science. 321.

https://digitalcommons.unl.edu/animalscifacpub/321

This Article is brought to you for free and open access by the Animal Science Department at DigitalCommons@University of Nebraska - Lincoln. It has been accepted for inclusion in Faculty Papers and Publications in Animal Science by an authorized administrator of DigitalCommons@University of Nebraska - Lincoln. 
Veum, T. L., J. T. Gallo, W. G. Pond, L. D. Van Vleck, and J. K. Loosli. 1965. Effect of ferrous fumarate in the lactation diet on sow milk iron, pig hemoglobin and weight gain. Journal of Animal Science 24:1169-1173.

Abstract: Two experiments involving 22 litters were conducted to study the effects of adding ferrous fumarate to the lactation diet on iron level of sow's milk and on weight gains and hemoglobin levels of suckling pigs. Ferrous fumarate was not effective in increasing iron content of milk, when added to the lactation diet at a level of $1984 \mathrm{mg}$. of iron per kg. The increase in hemoglobin level observed at 24 days in Experiment I and at 21 days in Experiment II, in litters nursing sows fed ferrous fumarate, was due to the pigs' obtaining a source of iron from the sow's feed and feces. When this contamination was prevented, no significant increase in hemoglobin level was obtained. Pigs injected with iron dextran were not significantly affected by the sow's diet; however, the injected pigs had significantly higher hemoglobin values than noninjected pigs. There was no significant difference in weight gains of pigs due to the sow's diet or to iron dextran injections at 21 or 24 days, when the iron injections were given at 7 and 10 days of age, respectively.

Copyright $\odot 1965$ American Society of Animal Science. Used by permission. 


\title{
EFFECT OF FERROUS FUMARATE IN THE LACTATION DIET ON SOW MILK IRON, PIG HEMOGLOBIN AND WEIGHT GAIN ${ }^{1}$
}

\author{
T. L. Veum, J. T. Gallo, W. G. Pond, L. D. Van Vleck and J. K. Loosli \\ Cornell University, Ithaca, New York
}

$\mathrm{M}$ cGOWAN and Crichton (1924) reported that the addition of ferric oxide to the diet of lactating sows prevented anemia in suckling pigs. They suggested that the pigs obtained iron from the sow's feed and feces rather than from any increase in the iron content of the milk. Elvehjem et al. (1927) found the iron content of goat's milk was not increased by feeding either ferric oxide or ferrous sulfate. Hart et al. (1929), Hamilton et al. (1930) and Venn et al. (1947) also failed to demonstrate increased iron levels in sow's milk from the addition of iron salts to the diet. Pond et al. (1961) reported that intramuscular injection of iron into the sow during gestation or lactation did not increase placental or mammary transfer of iron.

Chaney and Barnhart (1963) and Hansard et al. (1964) indicated that the iron content of the sow's millk could be increased to levels sufficient to prevent baby pig anemia by adding ferrous fumarate to the lactation diet. Catron et al. (1963) also found that ferrous fumarate aided in the prevention of baby pig anemia when fed to lactating sows. Other data presented by Hooks et al. (1963) and Miller et al. (1964) have not confirmed this response with ferrous fumarate. This suggests that the observed increase in hemoglobin may be the result of pigs' obtaining iron from the sow's diet and from her feces.

This study was undertaken to determine the effect of ferrous fumarate supplementation of the diet fed the lactating sow on milk iron content and on weight gains and hemoglobin levels of the suckling pigs.

\section{Experimental Procedure}

Experiment I. Ten Yorkshire sows were randomly allotted at farrowing to either a basal diet or the basal supplemented with $1984 \mathrm{mg}$. of elemental iron as ferrous fumarate per kilogram of diet. Composition of the basal diet in percent was as follows: yellow corn (No. 2), 73.0; dehydrated alfalfa meal, 10.0 ; meat scraps, 6.0 ; soybean meal, 10.0 ;

\footnotetext{
1 Supported in part by Walnut Grove Products Company Inc., Atlantic, Iowa.
}

trace mineralized salt, 0.5 ; dicalcium phosphate, 0.3 ; and vitamin supplement, ${ }^{2} 0.25$. By analysis the diet contained $13.3 \%$ protein and 1896 and $157 \mathrm{mg}$. of iron per kilogram of diet with and without supplementation, respectively. The sows were kept in concretefloored pens with their litters during the 24day study, and the pens were cleaned once daily. The pigs were not given creep feed while the sows were fed ad libitum. One-third to one-half of the pigs in each litter were injected intramuscularly with $150 \mathrm{mg}$. of iron as iron dextran ${ }^{3}$ at about 10 days of age.

Milk samples were obtained by machine (Hartman and Pond, 1960) on days 4, 12, 19 and 24 of the lactation period. Milk letdown was accomplished by intramuscular injection of 4 to $6 \mathrm{ml}$. of oxytocin. ${ }^{4}$ Milking was continued until milk ceased to flow. No particular precautions were taken to standardize the length of time between milking and previous nursing. A subsample of milk was removed for iron analysis ${ }^{5}$ using a modification of the A.O.A.C. (1960) colorimeter procedure. Blood samples were collected by puncture of the anterior vena cava, and individual body weights were recorded on the day of milking. Hemoglobin was determined by the method of Sanford and Sheard (1929).

Analysis of variance (with unweighted squares of means) was conducted as described by Steel and Torrie (1960). The sow mean square was used for testing differences between treatments. The error mean square (pigs within sows) was used for testing differences among sows.

Experiment 11. Since iron content of the milk was not increased by supplementing the sow diet with ferrous fumarate in Experiment I, this experiment was conducted to determine whether or not the hemoglobin increase observed at 24 days in Experiment $I$ in pigs nursing sows fed ferrous fumarate was due to

\footnotetext{
2 Hopro R, Borden Company, New York, N. Y.

3 Armour Pharmaceutical Company, Kankakee, Illinois, sup-

plied the Armidexan. tocin injection 20 U.S.P. units per mi.

Wainut Grove Products Company, Inc, Allantic. Iowa, Wainut Grove Products Company, Inc, Aflantic. Iowa,
supplied the feed grade ferrous fumarate and analyzed the milk samples for total iron at their chemical laboratory.
} 
TABLE 1. EFFECT OF FERROUS FUMARATE ON THE IRON CONTENT OF SOW'S MILK (EXPERIMENT I)

\begin{tabular}{|c|c|c|c|c|c|c|}
\hline \multirow[b]{2}{*}{ Sow diet } & \multirow[b]{2}{*}{ Sows } & \multicolumn{4}{|c|}{ Days postpartum } & \multirow[b]{2}{*}{ Av. } \\
\hline & & 4 & 12 & 19 & 24 & \\
\hline & no. & \multicolumn{5}{|c|}{$\ldots \mathrm{mcg} / 100 \mathrm{ml} \ldots \ldots$} \\
\hline $\begin{array}{l}\text { Basal } \\
\text { Basal + iron a }\end{array}$ & $\begin{array}{l}5 \\
5\end{array}$ & $\begin{array}{c}143 \\
96^{*}\end{array}$ & $\begin{array}{r}117 \\
89\end{array}$ & $\begin{array}{l}153 \\
124\end{array}$ & $\begin{array}{l}157 \\
136\end{array}$ & $\begin{array}{l}143 \\
111\end{array}$ \\
\hline
\end{tabular}

their rooting in the sow feed or feces, or to the possibility that iron in the milk of sows fed ferrous fumarate was in a more readily available form than that of control sows.

Twelve Yorkshire sows were allotted to either the contaminated (pigs had access to the sow's feed and feces) or the uncontaminated (pigs did not have access to the sow's feed or feces) group at farrowing. The six sows in each group were then randomly allotted to either the basal diet or the basal supplemented with $1984 \mathrm{mg}$. of elemental iron as ferrous fumarate per kilogram of diet. The basal diet was the same as that in Experiment I, except that corn was increased from 73.0 to $76.9 \%$, soybean meal from 10.0 to $11.0 \%$ and vitamin supplement from 0.2 to $0.3 \%$ at the expense of alfalfa meal. By analysis the diet contained $16.0 \%$ protein and 1882 and 150 of iron per $\mathrm{kg}$. of diet with and without supplementation, respectively.

The management of the contaminated group was similar to that of Experiment I. The sows were fed twice daily in the pens with their litters, and the pens were cleaned daily.

The sows in the uncontaminated group were fed and exercised for $1 \mathrm{hr}$. twice daily in pens separate from their litters. The sows became accustomed to defecating while they were in the exercise area. These sows were kept in farrowing crates which localized the area contaminated with feces and allowed the attend- ant to remove any noticeable fecal accumulation. Manure catchers ${ }^{6}$ were used in the farrowing crates in this experiment, although they served no useful purpose.

The pigs were not given creep feed during the experiment. One-third to one-half of the pigs in each litter were injected with $200 \mathrm{mg}$. of iron as iron dextran at 7 days of age.

Milk and blood samples were obtained by the methods used in Experiment $I$ on days 7, 14 and 21 during this 21-day study. Iron content of the milk and hemoglobin determinations are the same as in Experiment $\mathrm{I}$. Analyses of variance (unweighted squares of means) and Duncan's multiple range test were conducted as described by Steel and Torrie (1960).

\section{Results and Discussion}

There were no noticeable digestive disturbances due to the high level of iron in the supplemented diet. The feces from sows fed ferrous fumarate were dark and adhesive and appeared to be very high in iron, as compared with feces from sows consuming the basal diet.

Experiment I. There was no significant difference in the iron content of milk (table 1) associated with sow diet for each week of the experiment, except at 4 days postpartum when sows on the basal diet had a higher iron level in the milk than sows fed ferrous fumarate.

There were no significant differences in pig weight gains (table 2) as a result of feeding iron to the sows or injecting the pigs with iron dextran. Since the iron injections were given at about 10 days of age, this 24-day study was too short to detect a significant difference in weight gains between the injected and noninjected groups as has been reported by Ullrey et al. (1959), Zimmerman et al.

6 Patented by the Monastery of Conyers, Conyers, Georgia

TABLE 2. EFFECT OF FERROUS FUMARATE ON WEIGHT GAINS OF SUCKLING PIGS (EXPERIMENT I)

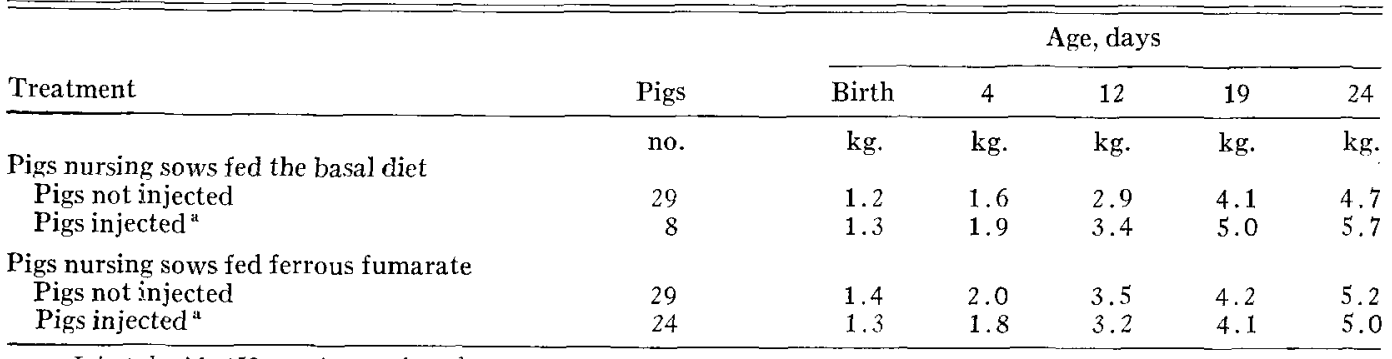

a Injected with $150 \mathrm{mg}$. iron as iron dextran at an average age of 10 days. 
(1959), Gehle et al. (1961) and Kernkamp et al. (1962).

Analyses showed no significant difference in hemoglobin level (table 3 ) due to iron level of the sow's diet except at 24 days, when a significant hemoglobin increase was observed in pigs nursing sows fed ferrous fumarate. The groups injected with iron dextran had similar hemoglobin levels which were not significantly affected by the sow's diet. However, the injected groups showed significantly higher hemoglobin values than either of the noninjected groups at 24 days of age. This agrees with the results of Burke et al. (1964a, b).

Experiment II. The data for the iron content of milk (table 4) are similar to those in Experiment I. There was no significant difference in the iron content of milk due to the iron level of the sow's diet for each week of the experiment.

TABLE 3. EFFECT OF FERROUS FUMARATE ON THE HEMOGLOBIN LEVELS OF SUCKLING PIGS (EXPERIMENT I)

Treatment
$\begin{aligned} & \text { Pigs nursing sows fed the } \\ & \text { basal diet }\end{aligned}$
$\begin{aligned} & \text { Pigs not injected } \\ & \text { Pigs injected }\end{aligned}$

Data on pig weights and hemoglobin levels, when the suckling pigs had access to the sow's feed and feces, are summarized in tables 5 and 6 , respectively. Weight gains were not influenced significantly by the sow's diet, although the pigs nursing sows fed ferrous fumarate outgained the pigs nursing sows fed the basal diet. Although weight gains were not affected significantly by iron injections, the injected pigs were slightly heavier than those not injected. The duration of this 21-day study was, as in Experiment I, apparently too short to observe a significant difference in weight gains between the injected and noninjected groups.

The hemoglobin values are also in close agreement with those of Experiment I. No significant difference in hemoglobin level due to the sow's diet was found, except at 21 days when a significant increase in hemoglobin
TABLE 4. EFFECT OF FERROUS FUMARATE ON THE IRON CONTENT OF SOW'S MILK (EXPERIMENT II)

\begin{tabular}{|c|c|c|c|c|c|}
\hline \multirow[b]{2}{*}{ Sow diet } & \multirow[b]{2}{*}{ Sows } & \multicolumn{3}{|c|}{ Days postpartum } & \multirow[b]{2}{*}{ Av. } \\
\hline & & 7 & 14 & 21 & \\
\hline & no. & - & ncg./ & $\mathrm{ml}$ & - \\
\hline $\begin{array}{l}\text { Contaminated group } \\
\text { Basal } \\
\text { Basal + iron }\end{array}$ & $\begin{array}{l}3 \\
3\end{array}$ & $\begin{array}{l}135 \\
136\end{array}$ & $\begin{array}{l}133 \\
126\end{array}$ & $\begin{array}{l}147 \\
125\end{array}$ & $\begin{array}{l}138 \\
129\end{array}$ \\
\hline $\begin{array}{l}\text { Uncontaminated group } \\
\text { Basal } \\
\text { Basal + irona }\end{array}$ & $\begin{array}{l}3 \\
3\end{array}$ & $\begin{array}{l}153 \\
148\end{array}$ & $\begin{array}{r}146 \\
94\end{array}$ & $\begin{array}{l}142 \\
101\end{array}$ & $\begin{array}{l}147 \\
115\end{array}$ \\
\hline
\end{tabular}

* Contained $1894 \mathrm{mg}$. of elemental iron $/ \mathrm{kg}$. of diet as ferrous fumarate.

level was observed in pigs nursing sows fed ferrous fumarate. The pigs injected with iron dextran had similar hemoglobin levels which were not significantly affected by the sow's diet; however, injected pigs had significantly higher hemoglobin levels than noninjected pigs at 14 and 21 days of age, respectively.

Tables 7 and 8 summarize the data on pig weights and hemoglobin levels, respectively, when iron contamination was prevented. The weight gains were not significantly different in any of the treatments, although the injected pigs and pigs nursing sows fed ferrous fumarate were slightly heavier than the noninjected pigs and pigs nursing sows fed the basal diet at 21 days of age. However, the important effect of preventing contamination is shown in the data in table 8 , where no significant difference in hemoglobin level due to the sow's diet was observed at 21 days. This indicates that the hemoglobin increases observed at 24 days in Experiment $\mathbf{I}$ and at 21 days in the contaminated group of Experiment II resulted from the pigs' obtaining a source of iron from the feed and feces of sows fed ferrous fumarate and not from any significant increase in milk iron content or milk iron availability.

The results of these experiments clearly indicate that ferrous fumarate is not effective in increasing milk iron content, in contrast to

TABLE 5. EFFECT OF FERROUS FUMARATE ON PIG WEIGHT GAINS IN THE CONTAMINATED GROUP (EXPERIMENT II)

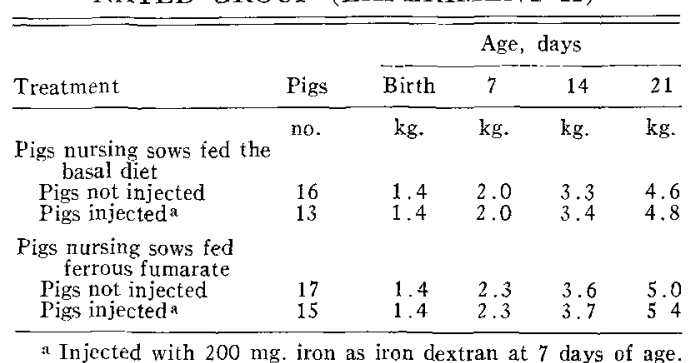

a Injected with $200 \mathrm{mg}$. iron as iron dextran at 7 days of age. 
TABLE 6. EFFECT OF FERROUS FUMARATE ON HEMOGLOBIN LEVELS OF SUCKLING PIGS IN THE CONTAMINATED GROUP (EXPERIMENT II)

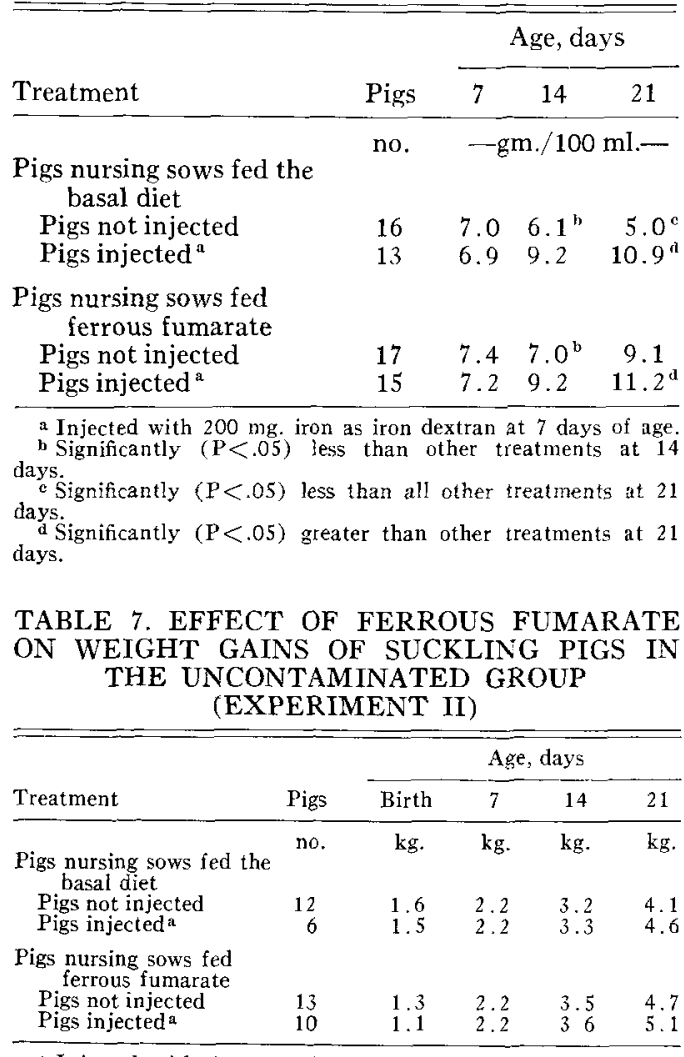
ge.

a Injected with $200 \mathrm{mg}$. iron as iron dextran at 7 days of

TABLE 8. EFFECT OF FERROUS FUMARATE ON HEMOGLOBIN LEVELS OF SUCKLING PIGS IN THE UNCONTAMINATED GROUP (EXPERIMENT II)

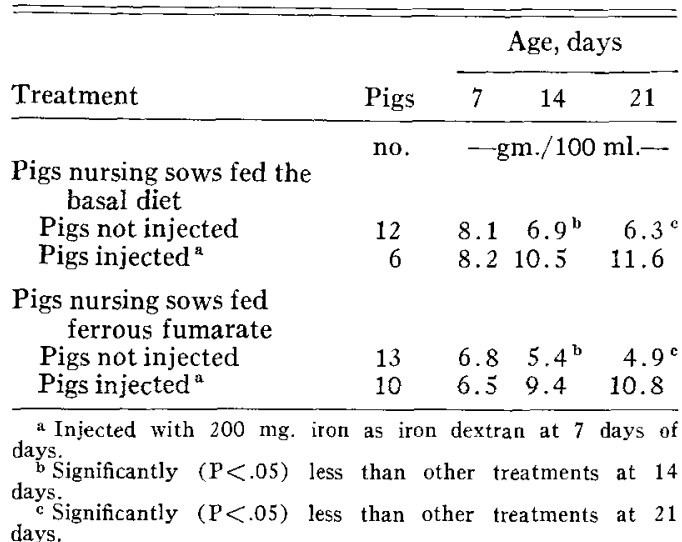

the results reported by Chaney and Barnhart (1963) and by Hansard et al. (1964). An in- crease in milk iron content of the magnitude obtained by those workers could not account for the hemopoietic response observed. Our results agree with those of earlier workers (Elvehjem et al., 1927; Hart et al., 1929; Hamilton et al., 1930; Venn et al., 1947) in showing no significant transfer of iron from the diet of the lactating sow into the milk. Ferrous fumarate may have application in anemia prevention when fed directly to the pig (Burke et al., 1964), but it appears not to occupy a special place among other iron compounds in mammary transfer.

\section{Summary}

Two experiments involving 22 litters were conducted to study the effects of adding ferrous fumarate to the lactation diet on iron level of sow's milk and on weight gains and hemoglobin levels of suckling pigs. Ferrous fumarate was not effective in increasing iron content of milk, when added to the lactation diet at a level of $1984 \mathrm{mg}$. of iron per $\mathrm{kg}$. The increase in hemoglobin level observed at 24 days in Experiment $\mathrm{I}$ and at 21 days in Experiment II, in litters nursing sows fed ferrous fumarate, was due to the pigs' obtaining a source of iron from the sow's feed and feces. When this contamination was prevented, no significant increase in hemoglobin level was obtained. Pigs injected with iron dextran were not significantly affected by the sow's diet; however, the injected pigs had significantly higher hemoglobin values than noninjected pigs. There was no significant difference in weight gains of pigs due to the sow's diet or to iron dextran injections at 21 or 24 days, when the iron injections were given at 7 and 10 days of age, respectively.

\section{Literature Cited}

A.O.A.C. 1960. Official Methods of Analysis. Association of Official Agricultural Chemists. Washington, D.C. p. 74.

Burke, R. P., L. Volker and E. Lorenz. 1964a. Effect of ferrous fumarate as an effective preventive of anemia in baby pigs. 1. Ferrous fumarate given to the sow by mouth. Landwirtsch. Forsch. 17:33.

Burke, R. P., L. Volker and E. Lorenz. 1964b. Ef fect of ferrous fumarate as an effective preventive of anemia in baby pigs. 2. Ferrous fumarate given to the suckling pig by mouth. Landwirtsch. Forsch. 17:137.

Catron, D. V., L. F. Nelson, F. Diaz and F. O. Lux. 1963. Anemia prevention in baby pigs via the sow lactation ration. J. Animal Sci. 22:833. (Abstr.).

Chaney, C. H. and C. E. Barnhart. 1963. Eiffect of iron supplementation of sow rations on the prevention of baby pig anemia. J. Nutr. 81:187. 
Elvehjem, C. A., R. C. Herrin and E. B. Hart. 1927. Iron in nutrition. III. The effects of diet on the iron content of milk. J. Biol. Chem. 71:255.

Gehle, M. H., L. C. Payne, E. R. Peo, Jr., and C. L. Marsh. 1961. Anemia in suckling pigs. J. Am. Vet. Med. Assn. 138:81.

Hamilton, T. S., G. E. Hunt, H. H. Mitchell and W. E. Carroll. 1930. The production and cure of nutritional anemia in suckling pigs. J. Agr. Res. 40:927.

Hansard, S. L., J. V. Lowe and D. M. Thraser. 1964. Nursing pigs' response to dietary iron levels fed lactating sows. J. Animal Sci. 23:300. (Abstr.).

Hart, E. B., C. A. Elvehjem, H. Steenbock, A. R. Kremmer, G. H. Bohstedt and J. M. Fargo. 1929. A study of anemia in young pigs and its prevention. J. Nutr. 2:277.

Hartman, D. A. and W. G. Pond. 1960. Design and use of a milking machine for sows. J. Animal Sci. 19:780.

Hooks, R. D., V. W. Hays, V. C. Speer and J. F. McCall. 1963. Control of baby pig anemia by feeding high levels of iron to lactating sows. J. Animal Sci. 22:1122. (Abstr.).

Kernkamp, H. C. H., A. J. Clawson and R. H. Ferneyhough. 1962. Preventing iron deficiency anemia in baby pigs. J. Animal Sci. 21:527.
McGowan, J. P. and A. Crichton. 1924. Iron deficiency in pigs. Biochem. J. 18:265.

Miller, E. R., D. E. Ullrey, C. L. Zutaut, B. H. Vincent, D. J. Ellis, R. W. Luecke and J. A. Hoefer. 1964. Supplementation of sow lactation diet with ferrous fumarate. J. Animal Sci. 23:884. (Abstr.).

Pond, W. G., R. S. Lowrey, J. H. Maner and J. K. Loosli. 1961. Parenteral iron administration to sows during gestation or lactation. J. Animal Sci. 20:747.

Sanford, H. and C. Sheard. 1929. A photoelectric hemoglobinometer. J. Lab. Clin. Med. 14:558.

Steel, R. G. D. and J. H. Torrie. 1960. Principles and Procedures of Statistics. McGraw-Hill Book Co., Inc., New York.

Ullrey, D. E., E. R. Miller, D. R. West, D. A. Schmidt, R. W. Seerley, J. A. Hoefer and R. W. Luecke. 1959. Oral and parenteral administration of iron in the prevention and treatment of baby pig anemia. J. Animal Sci. 18:256.

Venn, J. A. J., R. A. McCance and E. M. Widdowson. 1947. Iron metabolism in piglet anemia. J. Comp. Pathol. Therap. 57:314.

Zimmerman, D. R., V. C. Speer, V. W. Hays and D. V. Catron. 1959. Injectable iron-dextran and several oral iron treatments for the prevention of iron-deficiency anemia of baby pigs. J. Animal Sci. 18:1409. 